\title{
The research of contamination regularities of historical buildings and architectural monuments by methods of computer modeling
}

\author{
Andrey A. Kuzmichev ${ }^{1, *}$, Valeriy N. Azarov ${ }^{1}$, and Alexander V. Kuzmichev ${ }^{1}$ \\ ${ }^{1}$ Institute of Architecture and Civil Engineering of Volgograd State Technical University (IACE of VSTU), The Department of Life \\ Safety in Civil Engineering and Municipal Economy, Akademicheskaya str., 1, 400074, Volgograd, Russia
}

\begin{abstract}
Due to the active step of urbanization and rapid development of industry the external appearance of buildings and architectural monuments of urban environment from visual ecology position requires special attention. Dust deposition by polluted atmospheric air is one of the key aspects of degradation of the facades of buildings. With the help of modern computer modeling methods it is possible to evaluate the impact of polluted atmospheric air on the external facades of the buildings in order to save them.
\end{abstract}

\section{Introduction}

Nowadays due to the active step of urbanization and rapid development of industry, the appearance of historical buildings and architectural and cultural monuments of modern cities requires special attention. Dust deposition by polluted air is one of the key aspects of the deterioration of the facades of buildings. Owing to the modern computer modeling methods, it is possible to evaluate the impact of dusty ambient air on the external facades of buildings in order to save them, because it is a demonstration of architectural, structural and design features of various temporary periods.

\section{Current state of the problem of contaminated air influence on the appearance of historical buildings and architectural monuments}

Air pollution is associated with natural processes, such as cosmic dust, volcanic activity, dust forms as a result of destruction of rocks etc., also with anthropogenic processes, associated with the development of industry, agriculture and household economy, transport activity etc. $[1,10]$.

The World Health Organization acknowledged the negative impact of polluted atmospheric air on the health of inhabitants of cities, and the most dangerous pollutants for human, in addition to nitrogen oxides, sulfur dioxide, carbon monoxide and ground-level ozone, are particulate matters $-\mathrm{PM}_{10}$ and $\mathrm{PM}_{2,5}$. Their inclusion in the list of especially dangerous pollutants gave a powerful impetus to the development of a large number of studies on the treatment of these particles in different conditions and for different types of economic activities in order to reduce their content in the atmospheric air.
Based on studies conducted in Italy, the effect of air pollution on cultural heritage of the country was found. It turned out, that about $30 \%$ of destructions and damages to monuments and works of art took place because of air pollution [2]. Joint effect of aggressive solid, liquid and gaseous contaminants in the air combined with high humidity of ambient air reduce the endurance term of the different structural pieces and in general all building and facilities [3]. On the external facades of buildings black crusts are formed and dust is deposited due to impact of gases and particles, leading to undesirable aesthetic effects and also compromising the integrity of the materials [4].

\section{Visual ecology as a new scientific direction}

In the study of contamination regularities of historical buildings and architectural monuments it is necessary to consider the following aspects in total in order to achieve the best results in this field: physical aspect (it considers degradation of the exterior facades of buildings by means of dust, acid deposition, etc.), as well as visual aspect, covering visual perception of the environment [1].

Visual ecology is a science which studies and explains origins and mechanisms from the standpoint of modern psychophysiological science and gives theoretical basis for development of ecological principles of creation of material objects, which would respond the standards of a comfortable visual perception of the human environment [5]. The essence of the comfortable visual environment concept can be explained by the theory of «saccade automation» position in the example of the natural environment - a forest [6]. The term «saccade», introduced in the usage by Russian scientist V.A. Filin, represents quick eye movements aimed to change an observed object. It emphasizes the need of

\footnotetext{
Corresponding author: andrew 9207@mail.ru
} 
constantly updating the attentional objects [7]. In a forest landscape the number of elements for an eye analysis is uncountable, including visual dominants (single tree, open views, water, etc.). Upon the infinite transition from one element to another element it is capable for our eyes to have a rest [6].

\section{The experimental part}

\subsection{Experimental Installation Description and the Methods of Research}

In order to reduce the level of aggressiveness of urban visual environment by maintaining the external appearance of historical buildings and monuments of architecture and culture, we conduct the researches allowing to study in total physical and visual aspects of contamination of building constructions. Data were obtained and processed for the period of 2014 - 2016. It was solved to create two sampling sites: №1 - in Central district of Volgograd (Russia) in close proximity to the main highway of the city; №2 - in Krasnoslobodsky district (Volgograd region, Russia) away from busy roads (habitat). In order to study visual aspect of contamination of building constructions, the sampling sites were painted in the colours of buildings of the Stalin Era architecture (Fig. 1). Therefore, owing to the visual analysis of the sampling sites we can make conclusions on the extent of degradation of the external facades (dust, discoloration etc.) [5, 8, 9].

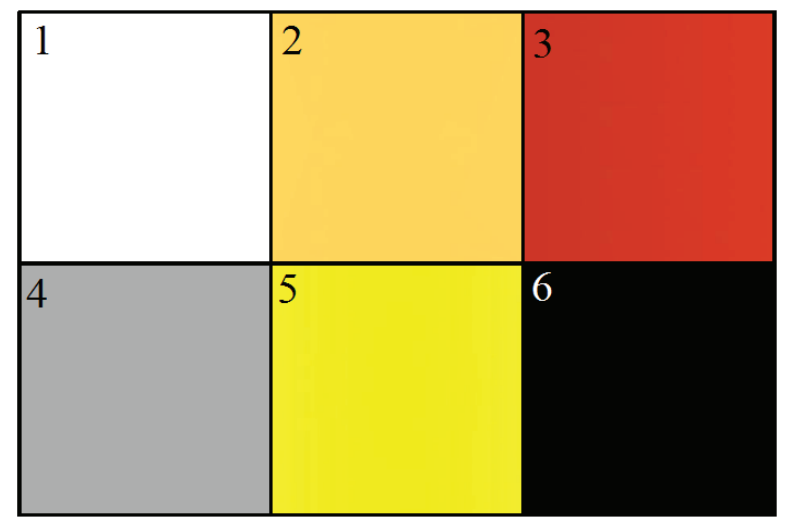

Fig. 1. Model of the sampling site: 1-white, 2-beige, 3-vinous, 4-grey, 5-yellow, 6-black.

The microscopic analysis of the dust samples were produced by using a scanning electron microscope Versa 3D Dual Beam. The chemical (elemental) composition of the samples were studied by scanning transmission electron microscopy (STEM). The dispersion analysis of the samples were produced by microscopic studies of micrographs using the computer software Image J (Fig. 2) [24]. According to the results, integral and differential curves, histograms of numerical distribution of particle's diameter to the probabilistic-logarithmic coordinate system are modeled, where $\mathrm{D}\left(\mathrm{d}_{\mathrm{p}}\right), \%$ - a share of a total mass of particles, which consists of particles with a diameter less than $\mathrm{d}[14,22,23]$.
Further in the computer software STATISTICA [25] the values of Pearson's criterion and Kolmogorov's criterion were obtained. The significant level of 5\% was adopted (Fig. 3). The observing values of the criterions should be less than the theoretical values for submission to the logarithmic-normal distribution $[16,17,18]$.

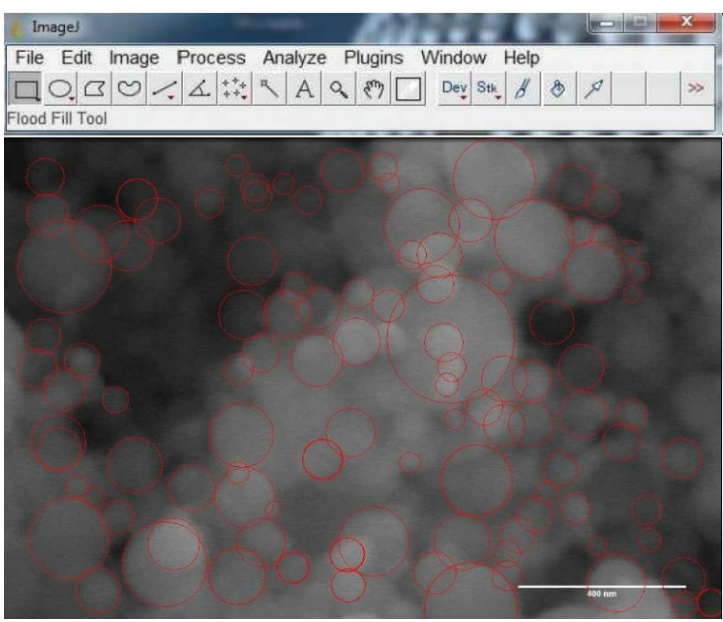

Fig. 2. Micrograph of the dust sample in the computer software Image J.

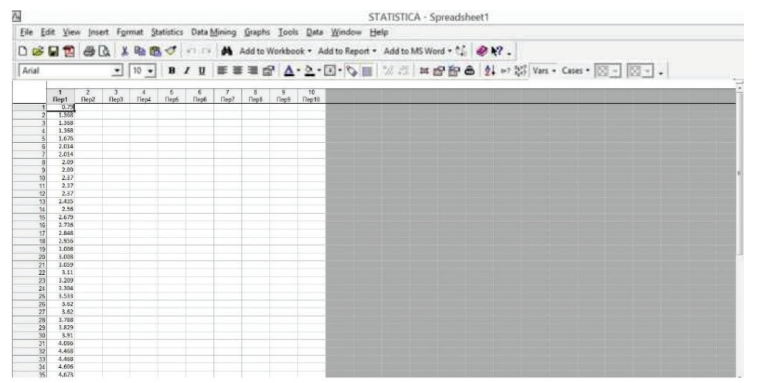

Fig. 3. The computer software STATISTICA.

\subsection{Processing of the results}

The results of the experimental studies of the dust samples were processed in selected urban environment and habitat for the period of 2014-2016. The results of the samples taken in the autumn 2015 on the site № 1 (Fig. 4) and in the autumn 2016 (Fig.5) were compared.

In the Fig. 4 the histogram of numerical distribution of the dust particles, selected in the autumn 2015 on the sampling site №1, is submitted. The amount of particles was 100 units. The size of the measured particles is in range from $0.79 \mu \mathrm{m}$ to $57.232 \mu \mathrm{m}$. The predominant sizes of dust particles are 2.5-5 $\mu \mathrm{m}$. The observed values of the criterions are less than the theoretical values (Table 1).

In the Fig. 5 the histogram of numerical distribution of the dust particles, selected in the autumn 2016 on the sampling site №2 is submitted. The amount of particles was 100 units. The size of the measured particles is ranged from $1.249 \mu \mathrm{m}$ to $25.178 \mu \mathrm{m}$. The predominant sizes of dust particles are $8-10 \mu \mathrm{m}$. The observed values of the criterions are less than the theoretical values (Table 2). 
The highest concentration of fine particles is observed during the summer period in urban environment (Fig. 6). The size of the measured particles is in range from $0.559 \mu \mathrm{m}$ to $25.983 \mu \mathrm{m}$. The predominant sizes of dust particles are $2-4 \mu \mathrm{m}$. The observed values of the criterions are less than the theoretical values (Table 3 ).

Based on the results the distributions are close to the logarithmic-normal. At the same time the size of particles in the habitat is lager than in the urban environment $[19,20,21]$.

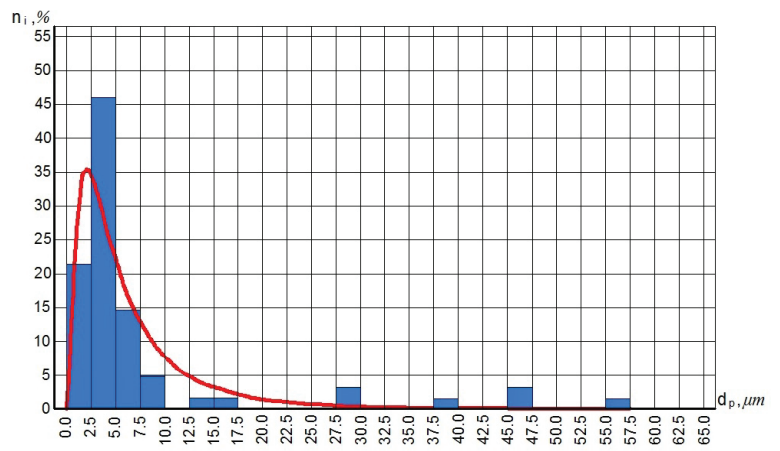

Fig. 4. The histogram of numerical distribution of dust particles on the sampling site №1 (autumn 2015).

Table 1. Values of the criterions according to the data on the site №1 (autumn 2015).

\begin{tabular}{|c|c|c|c|}
\hline \multicolumn{2}{|c|}{ Pearson's Criterion $\boldsymbol{\chi} \mathbf{2}$} & \multicolumn{2}{c|}{ Kolmogorov's Criterion } \\
\hline $\begin{array}{c}\text { Observed } \\
\text { Value }\end{array}$ & $\begin{array}{c}\text { Theoretical } \\
\text { value }\end{array}$ & $\begin{array}{c}\text { Observed } \\
\text { Value }\end{array}$ & $\begin{array}{c}\text { Theoretical } \\
\text { value }\end{array}$ \\
\hline 13.00845 & 67.328 & 0.11476 & 0.13403 \\
\hline
\end{tabular}

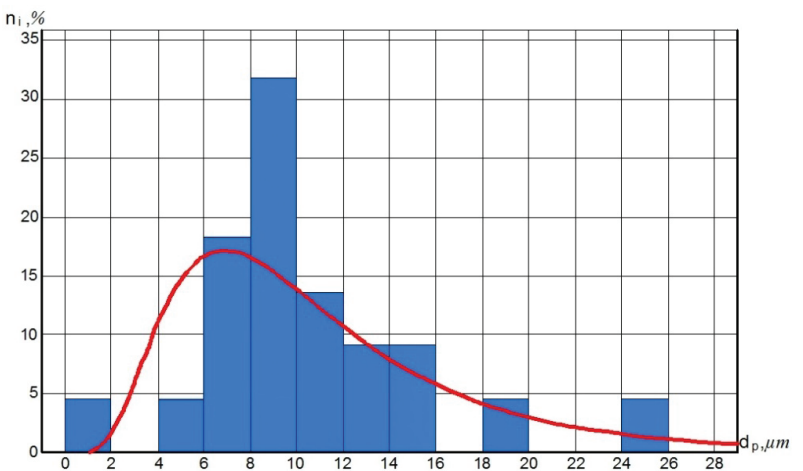

Fig. 5. The histogram of numerical distribution of dust particles on the sampling site №2 (autumn 2016).

Table 2. Values of the criterions according to the data on the site №2 (autumn 2016).

\begin{tabular}{|c|c|c|c|}
\hline \multicolumn{2}{|c|}{ Pearson's Criterion $\chi \mathbf{2}$} & \multicolumn{2}{c|}{ Kolmogorov's Criterion } \\
\hline $\begin{array}{c}\text { Observed } \\
\text { Value }\end{array}$ & $\begin{array}{c}\text { Theoretical } \\
\text { value }\end{array}$ & $\begin{array}{c}\text { Observed } \\
\text { Value }\end{array}$ & $\begin{array}{c}\text { Theoretical } \\
\text { value }\end{array}$ \\
\hline 11.31524 & 67.328 & 0.11763 & 0.13403 \\
\hline
\end{tabular}

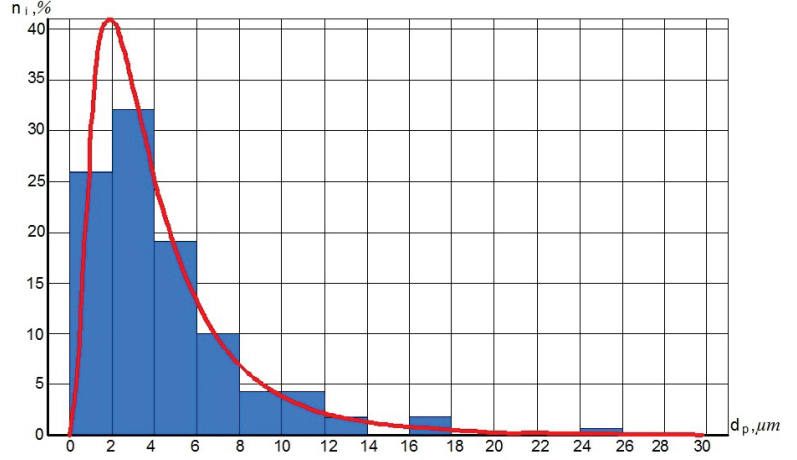

Fig. 6. The histogram of numerical distribution of dust particles on the sampling site №1 (summer 2016).

Table 3. Values of the criterions according to the data on the site №1 (autumn 2016).

\begin{tabular}{|c|c|c|c|}
\hline \multicolumn{2}{|c|}{ Pearson's Criterion $\boldsymbol{\chi 2}$} & \multicolumn{2}{c|}{ Kolmogorov's Criterion } \\
\hline $\begin{array}{c}\text { Observed } \\
\text { Value }\end{array}$ & $\begin{array}{c}\text { Theoretical } \\
\text { value }\end{array}$ & $\begin{array}{c}\text { Observed } \\
\text { Value }\end{array}$ & $\begin{array}{c}\text { Theoretical } \\
\text { value }\end{array}$ \\
\hline 1.69971 & 67.328 & 0.01773 & 0.13403 \\
\hline
\end{tabular}

For an assessment of regularities of distribution of particulate composition of the dust samples, integral curves of mass distribution on equivalent diameters of particles in probabilistic-logarithmic grid were considered, where D $\left(d_{p}\right), \%$ - a share of a total mass of particles, which consists of particles with a diameter less than $\mathrm{d}[11,12,13,15]$.

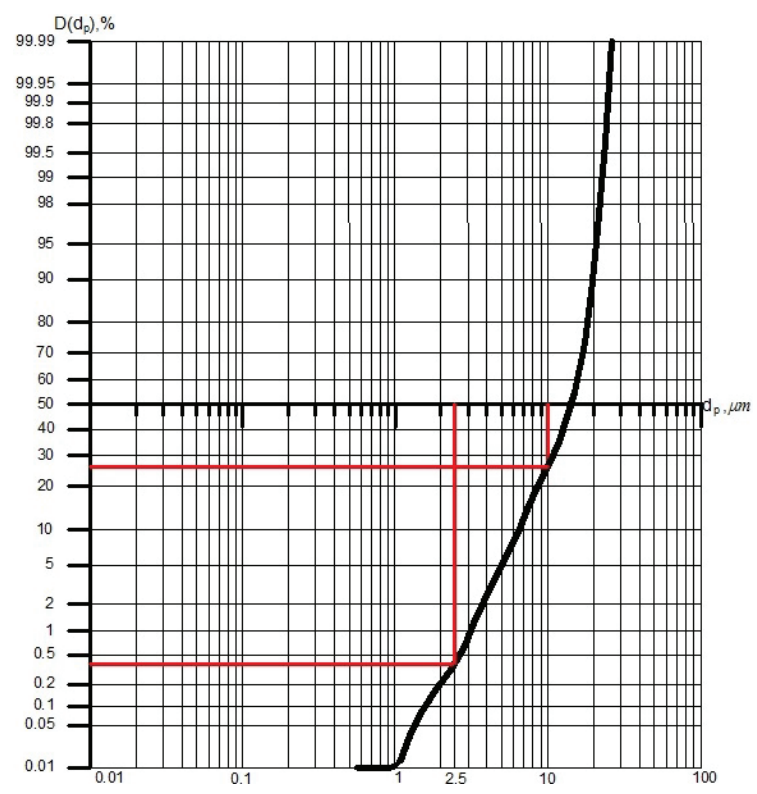

Fig. 7. Integral curve of mass distribution of dust particles on diameters on the sampling site №1 (summer 2016)

The integral curve (Fig. 7) shows, that Kolmogorov's law is observed only on certain areas, it can be represented by a two-unit spline. In general one can speak about a truncated logarithmic-normal distribution. 


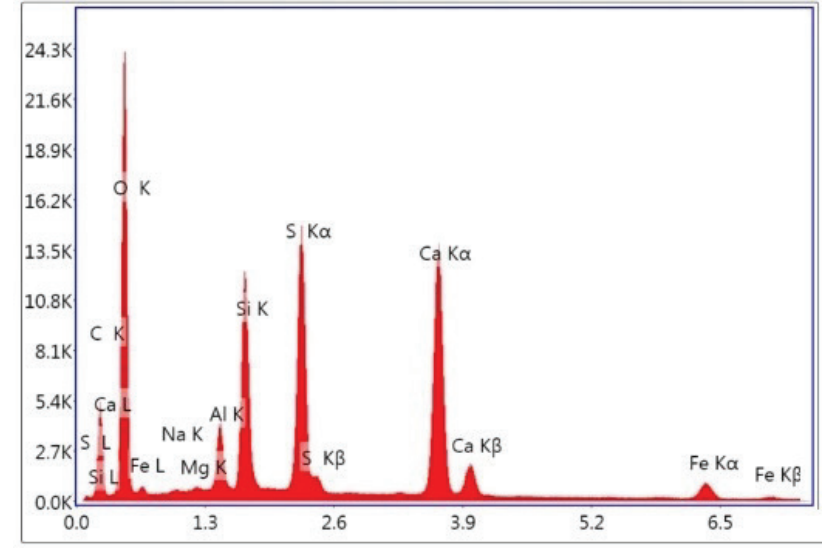

Fig. 8. Chemical (elemental) composition on the sampling site №1 (autumn 2016)

The analysis of chemical (elemental) composition of the samples, taken in the autumn 2016 on the site № 1 (urban environment) and on the site 2 № (habitat) shows, that the main components of the samples are the following substances: $\mathrm{O}, \mathrm{Si}, \mathrm{Ca}, \mathrm{S}$, Ti, was less significant content of components, such as $\mathrm{Al}, \mathrm{K}, \mathrm{Na}$, $\mathrm{Mg}, \mathrm{Fe}$. There is similar elemental composition on both sampling sites. Concentration on the site № 1 is higher because it is located in the urban environment, except for the concentration of $\mathrm{Si}$, which is higher on the site № 2 (habitat).

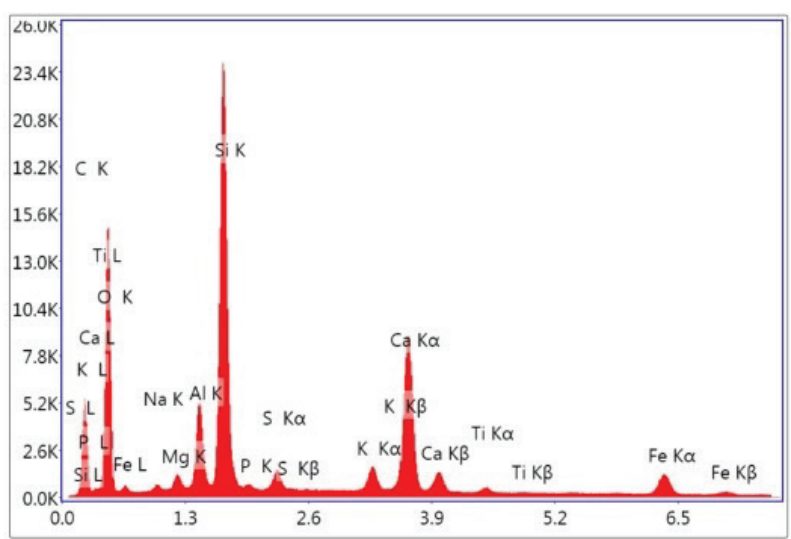

Fig. 9. Chemical (elemental) composition on the sampling site №2 (autumn 2016)

Besides there is a new type of particles-iberulites on the dust sample taken on the site №1 in the autumn 2016 (Fig. 10). This is a type of spherical aerosol particle with a vortex, made of a complex mineral assemblage that also contains biological remains. The most likely source areas based on inherent mineral components are the Sahara and Sahel, while other minerals are the results of atmospheric neoformation. The appearance of iberulites is a discontinuous phenomenon, occurring mainly during summer period and in dry periods corresponding to the highest total suspended particle contents. Thus, a correlation between amounts of dust and iberulites can be established; indeed, often their presence coincides with red dust rains and periods with no heavy rains [4].

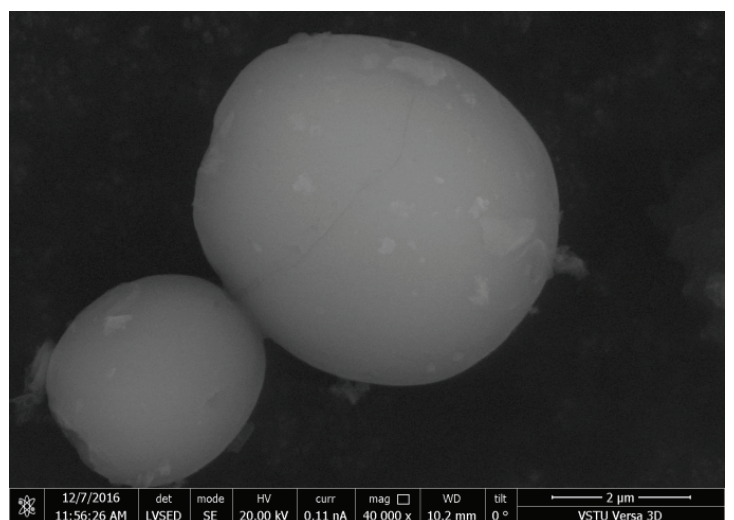

Fig. 10. Micrograph of the dust sample on the site № 1 (autumn 2016)

\section{Conclusion}

The need to preserve architectural heritage of historical and cultural value is getting more significant. At the same time it is very important to develop environment dynamically to sustain life activities in general. As modern life high rate does not allow an individual permanently or most of the time to be in a natural environment, the primary goal of visual ecology is to adapt urban environment to a comfortable perception by human. Due to the implementation of methods described in the article for the safety of building constructions and architectural monuments can be achieved the best results in this field of town planning [1].

\section{References}

1. A.A. Kuzmichev, V.F. Loboyko, Impact of polluted air on the appearance of buildings and architectural monuments in the area of town planning, Procedia Engineering 150, pp. 2095-210 (2016)

2. V.N. Azarov, A.A. Kuzmichev, Pollution of building constructions and architectural manuments as one of the aspects of visual ecology, Sotsiologiya Goroda [Sociology of City], no.2, pp. 76-86 (2015)

3. V. Kucera, S. Fitz, Direct and indirect air pollution effects on materials including cultural monuments. Water, air and soil pollution, Vol.51, №1, pp.153154 (1995)

4. V. Kontozova-Deutsch, C. Cardell, M. Urosevic et al., Characterization of indoor and outdoor atmospheric pollutants impacting architectural monuments: the case of San Jerónimo Monastery (Granada, Spain). Environ Earth Sci. 63:, pp.14331445 (2011)

5. V.N. Azarov, A.A. Kuzmichev, The totality of physical and visual aspects when studying contamination of building structures and monuments of architecture, Sotsiologiya Goroda [Sociology of City], no.3, pp. 28-42 (2016)

6. A.V. Gorodkov, S.I. Saltanova, Ekologiya vizual'noi sredy : uchebnoe posobie dlya vuzov. [Ecology of visual environment: work-book for higher education 
institutions]. 2nd edition (Saint-Petersburg. Lan' Publ., 2013)

7. A.A. Kuzmichev, On the problems of visual ecology of the urban environment, Problemy okhrany proizvodstvennoy i okruzhayushey sredy: sb. materialov i nauch. trudov inzhenerov-ekologov [Problems of protection of working space and the environment. Set of proceedings and scientific works of the environmental engineers]. Volgograd, PrinTerra-Design Publ., iss. 6. 103 p. (2015)

8. A.A. Kuzmichev, V.N. Azarov, The study of impact of air pollution on external appearance and perception of building constructions and architectural monuments, Biosfernaya sovmestimost: chelovek, region, tekhnologii [Biosphere compability: human, region, technologies], 1(13), pp. 86-96 (2016)

9. Nazim Y. Orudjev, Mikhail B. Lempert, Ivan Osaulenko, Natalia A. Salnikova, Andrew A. Kuzmichev, Alla G. Kravets, Computer - Based visual analysis of ecology influence on human mental health, 2016 7th International Conference on Information, Intelligence, Systems \&

Applications (IISA), IEEE Conference Publications, pp. 1-6 (2016)

10. V.N. Azarov, E.V. Gorshkov, R.M. Sarkisov, Construction sector of economy and atmospheric air in industrial cities, Sotsiologiya Goroda [Sociology of City], no.4, pp. 71-78 (2012)

11. Azarov V. N., Tertishnikov I. V., Marinin N. A. [Rating of PM10 and PM2.5 as Social Standards of Life Quality in Areas of Building Industry Enterprises Location]. Zhilishchnoe stroitel'stvo [Housing Construction], 2012, no. 3, pp. 20-23

12. V.N. Azarov, I.V. Tertishnikov, Ye.A. Kalyuzhina, N.A. Marinin, About concentration estimation of fine dust (PM10 u PM2,5) in air, Vestnik Volgogradskogo gosudarstvennogo arhitekturnostroitel'nogo universiteta. Seriya: Stroitel'stvo i arhitektura [Bulletin of Volgograd State University of Architecture and Civil Engineering. Series: Civil Engineering and Architecture], iss. 25(44), pp. 402-1061 (2011)

13. V.N. Azarov, N.A. Marinin, D.V. Jogoleva, About a Concentration Estimation Disperse a Dust (PM10 and PM2,5) In Atmosphere of Cities, Izvestiya Yugo-Zapadnogo gosudarstvennogo universiteta [Proceedings of the South-West state university], 5(38), part 2, pp. 144-149 (2011)

14. V.N. Azarov, V. Yu. Yurk"yan, N.M. Sergina, A.V. Kovaleva, Methodology of the microscopic analysis of dust disperse composition with the use of a personal computer (PC), Zakonodatel'naya i prikladnaya metrologiya [Legal and applied metrology], no. 1, pp. 46-48 (2004)

15. V.N. Azarov, N.A. Marinin, I.V. Burba, Estimation of PM[10] and PM [2,5] dust concentration with the help of the bisection method. Ekologicheskaya geologiya: teoriya, praktika i regional'nye problemy: materialy vtoroi mezhdunarodnoi nauch.- praktich. konf., g. Voronezh, $4-6$ okt. 2011 g. [Ecological geology: theory, practice and regional problems. Proc. of 2 Int. sci.-pract. conf., Voronezh, 4-6 October, 2011]. Voronezh, "KOMPIR" Center of documentation, pp. 285-287 (2011)

16. V. Azarov, N. Barikaeva, Monitoring of Fine Particulate Air Pollution as a Factor in Urban Planning Decisions, Procedia Engineering 150, pp. 2001-2007 (2016)

17. V. Azarov, M. Trokhimchyk, O. Sidelnikova, Research of Dust Content in the Earthworks Working Area, Procedia Engineering 150, pp. 20082012 (2016)

18. V.N. Azarov, D. P. Borovkov, A. M. Redhwan. Application of swirling flows in aspiration systems, International Review of Mechanical Engineering, vol. 8, iss. 4, pp. 750-753 (2014)

19. V.N. Azarov, D.V. Lukanin, D.P. Borovkov, A.M. Redhwan, Experimental study of secondary swirling flow influence on flows structure at separation chamber inlet of dust collector with counter swirling flows, International Review of Mechanical Engineering, vol. 8, iss. 5, pp. 851-856 (2014)

20. V.N. Azarov, I. N. Logachev, K. I. Logachev et al., Methods of reducing the power requirements of ventilation systems Part 4. The oretical prerequisites with swirling air flows. Refractories and industrial Ceramies, vol. 55, iss. 4, pp. 365-370 (2014)

21. V.N. Azarov, N. V. Menzelitseva et al., Main Trends of Conditions Normalizing at Cement Manufacturing Plants, International Review of Civil Engineering, vol. 6, no. 6, pp. 145-150 (2015)

22. Natalia A. Salnikova, Boris A. Lempert, and Mikhail B. Lempert, Integration of Methods to Quantify the Quality of Medical Care in the Automated Processing Systems of Medical and Economic Information. In: Communications in Computer and Information Science, vol. 535, CIT\&DS 2015, Volgograd, Russia, pp. 307-319 (2015)

23. Valery A. Kamaev, Ilya P. Mikhnev, Natalia A.Salnikova, Natural Radionuclides as a Source of Background Irradiation Affecting People Inside Buildings, Procedia Engineering, vol. 150, pp. 16631672 (2016)

24. V.N. Azarov, N.M. Sergina, Metodika mikroskopicheskogo analiza dispersnogo sostava pyli s primeneniem personal'nogo komp'yutera (PK). Dep. v VINITI. № 1332- 80002. 15.07.2002 [Methodology of the microscopic analysis of dust disperse composition with the use of a personal computer (PC). Depp. in VINITI. no. 1332-80002. 15 July, 2002].

25. Bureeva N.N. Mnogomerniy statisticheskiy analiz s ispolzovaniem PPP "STATISTICA" [Multivariate statistical analysis using computer software "STATISTICA"]. Nizhny Novgorod, 2007, 112p. 